\title{
HUBUNGAN ANTARA PERSEPSI MANAJEMEN LINI TERHADAP TURNOVER DI MANAJEMEN PUNCAK DENGAN KOMITMEN ORGANISASI
}

\author{
Susatyo Yuwono \\ Yadi Purwanto \\ Ade Kurniawan \\ Fakultas Psikologi Universitas Muhammadiyah Surakarta
}

\begin{abstract}
This research's aim is to find the correlation between line management's perception about top management's turnover and organizational commitment. The hypotesis is there is a correlation between line management's perception about top management's turnover and organizational commitment.

Population, as subject, are 37 line management's of PT Krakatau Engineering,. Data gathered by questionnaires: line management's perception about top management's turnover, and organizational commitment.

The analysis by product moment techniques, and the results shows correlation index $(r)=0,584, p<$ 0,01 . It means there is a positive very significant correlation between line management's perception about top management's turnover and organizational commitment.
\end{abstract}

Keyword: perception on turnover, organizational commitment

\section{PENDAHULUAN}

Awal tahun 2005 sebuah biro konsultan sumber daya manusia terkemuka, Watson Wyatt, mengadakan sebuah survei komprehensif dengan tema Work Indonesia 2004/2005 yang membedah pandangan karyawan di Indonesia. Survei tersebut menunjukkan sejumlah fakta menarik, diantaranya mengenai rendahnya tingkat loyalitas karyawan Indonesia (terendah se-Asia Pasifik) dan juga minimnya level kepercayaan terhadap manajemen senior (NN, 2005).

Kondisi perekonomian Indonesia dalam beberapa tahun belakangan ini memiliki tingkatan dinamika organisasi cukup tinggi. Termasuk didalamnya dinamika yang terjadi dalam manajemen puncak. Pergantian direksi Pertamina di tahun 2004, turnover Direktur Utama Bank Mandiri dipertengahan tahun 2005 hingga penggantian Direktur Utama PT Jamsostek dan PT Garuda Indonesia yang menjadi perbincangan masyarakat karena penunjukkan dilakukan secara langsung oleh Meneg BUMN tanpa melalui metode fit \& proper test (Kormen, 2005), perbedaan gaji dengan karyawan yang mencapai kesenjangan skala 1:100 ditambah dengan beragam benefit lain seperti fasilitas rumah dan mobil mewah, club membership, hingga kemungkinan kepemilikan saham diberikan sebagai pengikat dari perusahaan memaparkan beberapa dinamisasi yang terjadi disana (NN, 2005).

Kedudukan manajemen puncak memang sangat krusial. Dengan corporate mission yang diberikan oleh dewan komisaris, mereka diharuskan membuat strategic 
link dengan wewenang dan otorita untuk melakukan perubahan-perubahan yang diperlukan dengan tanggung jawab terbesar kepada dewan direksi ataupun pertanggungan secara keseluruhan kepada anggota organisasi. Seorang manajemen puncak menduduki posisi strategis yang mampu mempengaruhi keberlangsungan perusahaan melalui segala kebijakan dan kontribusi yang mereka berikan (Kotter, 1997).

Manajemen lini (kerap disebut juga dengan manajemen level atau manajemen pertama) dapat diidentifikasikan sebagai penghubung antara tingkatan manajemen dan para pekerja. Manajemen lini berperan ganda sebagai atasan, bawahan, rekan dan wakil perusahaan. Bedanya ialah bawahannya bukan memegang jabatan pimpinan. Manajemen lini juga disebut tenaga kerja-yang-berada-ditengah (the-manin-the-middle) antara manajemen dan para pekerja. Sehingga jika terdapat pandangan antara kedua pihak berbeda, maka manajer pertama akan merasa terjepit (Munandar, 2001).

Setiap pergantian manajemen puncak memberi pengaruh pada kehidupan organisasi secara keseluruhan, termasuk diantaranya manajemen lini. Beragam persepsi muncul mengenai alasan-alasan dari turnover sang dirut, termasuk penilaian mengenai kondisi perusahaan. Suatu turnover dapat menyebabkan turnover lanjutan dari karyawan lainnya (Krackhart \& Porter, 1986). Lalu bagaimana pandangan manajemen lini, sebagai line connector utama antara karyawan operasional dengan pihak manajemen, terhadap fenomena turnover yang terjadi akhirakhir ini disekitar manajemen puncak? Adakah hubungan antara penilaian akan turnover itu dengan komitmen organisasi mereka?

\section{LANDASAN TEORI DAN HIPOTESIS}

\section{Komitmen Organisasi}

Komitmen organisasi adalah suatu keadaan dimana seorang individu memihak pada suatu organisasi tertentu dengan tujuan-tujuannya serta berniat memelihara keanggotaan dalam organisasi tersebut. Allen \& Meyer (dalam Hapsari, 2004) mendefinisikan komitmen organisasi sebagai suatu kelekatan afeksi atau emosi terhadap organisasi seperti individu melakukan identifikasi yang kuat, memilih keterlibatan tinggi, dan senang menjadi bagian dari organisasi. Komitmen organisasi mengandung pengertian sebagai suatu hal yang lebih dari sekedar kesetiaan yang pasif terhadap organisasi, lebih dari sekedar loyalitas, karena komitmen organisasi menyiratkan hubungan pegawai dengan perusahaan atau organisasi secara aktif (Kuntjoro, 2002).

Faktor-faktor yang mempengaruhi komitmen individu pada organisasinya seperti yang disebutkan Steers \& Porter (dalam Panjaitan, 2005) cukup beragam, antara lain karakteristik pribadi (umur, masa kerja, motivasi berprestasi, dan pendidikan), karakteristik pekerjaan (tantangan kerja, kesempatan berinteraksi sosial, identitas tugas, dan umpan balik), desain organisasi (desentralisasi, derajat 
formalitas, dan derajat partisipasi dalam pengambilan keputusan) serta pengalaman kerja (merupakan bagian dari komponen kepuasan dari pengalaman kerja, perasaan dibutuhkan oleh organisasi, dan perasaan terpenuhinya harapan-harapan individu terhadap organisasi).

Peter, Mowday dan Steers (dalam Sjabadhyni, 2001) menyebutkan dua faktor utama yang menunjang kekuatan sosialisasi utama dan mempengaruhi komitmen organisasi karyawan, yaitu faktor lingkungan dan pengalaman kerja.

Para ahli mengungkapkan berbagai aspek-aspek yang terdapat dalam komitmen organisasi. Steers (dalam Kuntjoro, 2002) menyebutkan tiga aspek utama dari komitmen organisasi, yaitu:

a. Identifikasi, yaitu bentuk kepercayaan pegawai terhadap organisasi.

b. Keterlibatan atau partisipasi pegawai dalam aktivitas-aktivitas kerja.

c. Loyalitas.

Charles O'Reilly (dalam Sjabadhyni, 2001) juga berpendapat kurang lebih sama, tiga aspek yang membentuk komitmen organisasi antara lain:

a. Kerelaan dan kepatuhan, dimana individu bersedia menerima pengaruh dari orang lain dan patuh terhadap setiap tugas atau perintah yang diberikan padanya.

b. Identifikasi; individu menerima pengaruh untuk mempertahankan suatu kepuasan yang berhubungan dengan identifikasi diri serta rasa bangga memiliki organisasi.

c. Internalisasi, yaitu individu merasakan nilai-nilai organisasi secara intrinsik sesuai atau relatif sama dengan nilai-nilai pribadinya.

Aspek-aspek yang membentuk komitmen organisasi yaitu: 1) internalisasi, 2) optimalisasi, dan 3) loyalitas.

\section{Persepsi Manajemen Lini terhadap Turnover Manajemen Puncak}

Stanton (1996) mendefinisikan persepsi sebagai makna yang kita perhatikan berdasarkan pengalaman masa lalu, stimuli (rangsangan-rangsangan) yang kita terima melalui indera. Tak jauh berbeda, Kotter (2000) menjelaskan persepsi sebagai proses bagaimana seseorang menyeleksi, mengatur dan menginterpretasikan masukan-masukan informasi untuk menciptakan gambaran keseluruhan yang berarti. Maier (dalam Mobley, 1986) dan Staw (1991) mengartikan turnover sebagai perpisahan antara perusahaan dan pekerja. Mobley sendiri (1986) menyatakan bahwa turnover adalah berhentinya individu sebagai anggota sebuah organisasi yang disertai pemberian imbalan keuangan oleh organisasi yang bersangkutan. Persepsi manajemen lini terhadap turnover di manajemen puncak dapat disimpulkan sebagai pemahaman sekaligus penilaian akan fenomena turnover yang terjadi pada jajaran eksekutif manajemen puncak.

Robbins (2003) menjelaskan bahwa meskipun individu-individu memandang pada satu benda yang sama, mereka dapat mempersepsikannya berbeda-beda. Ada 
sejumlah faktor yang bekerja untuk membentuk dan terkadang memutar-balikkan persepi. Faktor-faktor ini terdiri dari:

a. Pelaku persepsi (perceiver)

b. Objek atau target yang dipersepsikan

c. Konteks dari situasi dimana persepsi itu dilakukan

Penelitian-penelitian mengenai turnover yang dipaparkan oleh Mobley (1986), Abelson dan Price (dalam Jewell \& Siegall, 1998) hingga Carrel (2002) mengklasifikasikan faktor-faktor yang mempengaruhi turnover dalam sisi prakarsa karyawan dan kendali organisasi.

Prakarsa karyawan dimaksudkan sebagai persetujuan individu dalam melakukan turnover. Kendali utama ada pada karyawan dengan beragam pilihan alasan seperti tawaran kompensasi yang lebih baik di perusahaan lain, desakan dari keluarga yang menginginkan karyawan memberikan waktu lebih banyak pada keluarganya, atau dapat juga karena permasalahan dengan pimpinan atau organisasi seperti perbedaan filosofi, ketidak cocokan dengan rekan kerja dan lainnya. Sedangkan kontrol organisasi berupa kendali perusahaan terhadap turnover tersebut, sehingga dalam kontrol organisasi ini karyawan tidak dapat melakukan interferensi atau mengubah keputusan turnover yang diberlakukan perusahaan. Alasan yang biasa digunakan antara lain karena karyawan memiliki kinerja rendah atau bisa juga dikarenakan faktor regenerasi dimana karyawan yang bersangkutan telah mencapai masa pensiunnya (Simamora, 2001).

Manajemen lini (disebut juga dengan manajemen level atau manajemen pertama) merupakan jajaran manajer yang tingkatannya paling bawah, setelah manajemen madya. Dalam operasinya mereka berhubungan langsung dengan pelaksana/karyawan operasional, dan karenanya mereka lebih banyak berperan sebagai penghubung antara tingkatan manajemen dan para pekerja (Haryani, 2002). Jauch \& Glueck (1998) secara singkat menerjemahkan manajemen lini sebagai dimensi manajerial yang membawahi sekelompok pekerja produksi.

Manajemen puncak dalam perjalanannya memiliki beberapa nama lain, seperti Chief Executive Officer (CEO), Presiden Direktur (Presdir) atau Direktur Utama (Dirut). Pada keutamaannya kesemua istilah itu memiliki pengertian yang sama, yaitu eksekutif yang berada di puncak perusahaan atau SBU (Stategic Business Unit) dan bertanggungjawab atas kelangsungan hidup dan keberhasilan perusahaan (Jauch \& Glueck, 1998).

Manajemen puncak memiliki perekrutan dan pemberhentian yang khusus dan berbeda dengan elemen persona lainnya. Seperti yang berlaku pada Direksi di Perseroan Terbatas, berdasarkan Undang-undang no.1 pasal 80 ayat 1 tahun 1995 mengenai Perseroan Terbatas (PT), Direksi dipilih dan diangkat oleh dewan komisaris selaku pemegang saham melalui Rapat Umum Pemegang Saham (Wijaya, 2003). 
Berdasarkan uraian di atas, hipotesis yang diajukan dalam penelitian ini adalah, ada hubungan antara persepsi manajemen lini terhadap turnover di manajemen puncak dengan komitmen organisasi.

\section{METODE PENELITIAN}

\section{Subjek penelitian}

Populasi dalam penelitian ini adalah manajer lini PT. Krakatau Engineering, dengan karakteristik usia antara 25-45, pendidikan minimal setingkat SMA, setingkat karyawan tetap, memiliki pengalaman kerja minimal 6 tahun di perusahaan, bukan merupakan anggota keluarga, relasi atau teman dekat dari manajer puncak. Diperoleh jumlah populasi 37 orang, yang semuanya dijadikan subjek penelitian.

\section{Alat ukur}

Alat ukur yang digunakan dalam penelitian ini ada dua, yaitu: 1) skala persepsi manajemen lini pada urnover manajemen puncak, dengan aspek ukur prakarsa individu (Reward \& compensation yang lebih baik di perusahaan lain, konflik dengan pimpinan/organisasi, faktor keluarga, dan kejenuhan pada pekerjaan) serta faktor kendali organisasi (low performance dan regenerasi), dengan koefisien validitas $\left(r_{b t}\right)$ berkisar antara 0,312 hingga 0,$767 ; 2$ ) skala komitmen organisasi dengan aspek ukur internalisasi nilai-nilai/tujuan perusahaan, kesediaan untuk bekerja semaksimal mungkin demi kepentingan perusahaan, keinginan yang kuat untuk mempertahankan keanggotaannya dalam perusahaan, dengan koefisien validitas $\left(r_{b t}\right)$ berkisar antara 0,312 hingga 0,670.

\section{HASIL DAN PEMBAHASAN}

Turnover yang terjadi di jajaran manajemen puncak berdampak pada karyawan, mulai dari bawahan pertama (manajemen madya) hingga karyawan operasional. Meskipun secara organisasional manajemen lini tidak berhubungan langsung dengan manajemen puncak, namun karena manajemen puncak merupakan tokoh kunci yang memegang peranan penting dalam penetapan arah kebijakan perusahaan, setiap turnover yang terjadi pada manajer puncak menjadi perhatian bagi lini. Hal ini dikuatkan dengan pendapat Staw (1991) yang menyebutkan bahwa semakin tinggi posisi yang ditinggalkan maka semakin tinggi pula kemungkinan tergganggunya kinerja organisasi (disebut juga dengan istilah turnover disfungsional).

Manajemen lini adalah jajaran organisasi yang berhubungan secara langsung dengan bidang operasional, karenanya mereka mempunyai tingkat kepekaan yang lebih tinggi dibandingkan dengan jajaran manajemen lainnya. Bila manajemen puncak bertugas merumuskan kebijakan-kebijakan umum organisasi, maka manajemen lini menjadi orang-orang yang diharapkan mampu meng- 
komunikasikan kebijakan-kebijakan tersebut secara lugas pada karyawan di bagian operasional dan mengaplikasikannya menjadi suatu bentuk nyata.

Persepsi manajemen lini terhadap turnover di manajemen puncak merupakan pemberian arti terhadap fenomena turnover dikalangan manajemen puncak. Perubahan-perubahan yang terjadi dalam organisasi tidak hanya disebabkan oleh turnover itu sendiri, tetapi disebabkan pula oleh faktor-faktor yang melatar belakanginya. Secara umum turnover ditentukan oleh faktor prakarsa individu dan kendali organisasi, seperti reward \& compensation yang lebih baik, konflik dengan pimpinan/organisasi, faktor keluarga, kejenuhan, low performance dan regenerasi. Hasil analisis data menunjukkan hubungan positif yang sangat signifikan antara persepsi manajemen lini terhadap turnover di manajemen puncak dengan komitmen organisasi, dengan kata lain persepsi manajemen lini terhadap turnover di manajemen puncak berpengaruh pada komitmen organisasi mereka. Masing-masing dari faktor turnover tersebut menciptakan suatu penilaian dari karyawan terhadap pelaku turnover dan pada akhirnya penilaian secara keseluruhan mengenai komitmen mereka pada organisasi.

Sumbangan efektif variabel persepsi manajemen lini terhadap turnover di manajemen puncak dengan komitmen organisasi sebesar 34,1\% (ditunjukkan dalam koefisien determinan $r^{2}$ sebesar 0,341. Dengan demikian terdapat 65,9\% faktorfaktor lain diluar variabel persepsi terhadap turnover yang dapat mempengaruhi komitmen manajemen lini terhadap perusahaan, seperti desain organisasi, karakteristik pekerjaan, dan faktor-faktor karakteristik pribadi (umur, masa kerja, motivasi berprestasi, pendidikan, dan pengalaman kerja).

Analisa data penelitian menunjukkan bahwa persepsi manajemen lini mengenai turnover di manajemen puncak tergolong "cukup tinggi" ditunjukkan oleh rerata empirik sebesar 73,862 dan rerata hipotetik 72,5 . Untuk komitmen organisasi juga termasuk "cukup tinggi" dengan rerata empirik 75,862 dan rerata hipotetik 75.

\section{SIMPULAN DAN SARAN}

Berdasarkan hasil penelitian dan pembahasan yang telah diuraikan sebelumnya, dapat disimpulkan bahwa ada hubungan positif yang sangat signifikan antara persepsi manajemen lini terhadap turnover di manajemen puncak dengan komitmen organisasi.

Manajemen madya sebagai atasan langsung dari manajemen lini sangat diharapkan dapat mengambil langkah lanjutan setelah menganalisa hasil penelitian ini. Kategori "cukup tinggi" dalam persepsi manajemen lini berarti manajemen lini cukup memahami kondisi-kondisi yang tercipta dalam turnover manajemen puncak. Kategori "cukup" dapat terjadi karena kesimpangsiuran informasi mengenai penyebab keluarnya sang manajer puncak. Untuk mengatasi hal tersebut, informasi dapat langsung dijelaskan pada manajer lini dengan demikian dapat mengeliminir kemungkinan penyebaran desas-desus yang beredar di karyawan. Para manajer 
madya dapat meningkatkan komitmen manajer lini mereka dengan cara memperbanyak frekuensi keterlibatan maupun intensitas komunikasi diantara keduanya lebih optimal lagi.

Bagi peneliti lain dapat lebih memperluas cakupan informasi baik berupa teori maupun kasus-kasus yang terkait sehingga dapat melakukan revisi alat ukur penelitian menjadi lebih baik. Aspek-aspek seperti beban kerja dan kondisi (kekuatan ekonomi) perusahaan dapat dimasukkan dalam varian aspek persepsi terhadap turnover di manajemen puncak. Peningkatan jumlah subyek dan perbaikan aitem pernyataan (terutama pada variabel persepsi manajemen lini terhadap turnover di manajemen puncak) juga perlu dilakukan dengan maksud memperkuat analisa data sehingga diharapkan dapat memberikan hasil yang lebih komprehensif.

\section{DAFTAR PUSTAKA}

Carrel, M. dkk. (2002). Human Resource Management: Global Strategies for Managing a Diverse Workforce. New Jersey: Prentice Hall.

Hapsari, W. Hubungan antara Persepsi terhadap Karakteristik Pekerjaaan dengan Komitmen Organisasi Karyawan PT SUCOFINDO (PERSERO). Skripsi (tidak diterbitkan). Surakarta: Fakultas Psikologi Universitas Muhammadiyah Surakarta.

Haryani, S. (2002). Hubungan Industrial di Indonesia. Yogyakarta: AMP YKPN.

Harris, M. (2000). Human Resource Management: a Practical Approach. Orlando: Harcourt

Jauch, L \& Glueck, W.F. (1998). Manajemen Strategis dan Kebijakan Perusahaan. Jakarta: Erlangga

Jewell, L.N \& Siegell, M. (1998). Psikologi Industri/Organisasi Modern. Jakarta: Arcan.

Kormen. (2005). Laporan Kinerja Ancam Posisi Direksi. Majalah Busines Review Edisi 05/IVIAgustus 2005. Jakarta: Ideku Group.

Kotter, J.P. (1982). Para Manajer Utama. Jakarta: Prenhallindo.

Krackhardt, D \& Porter, L.W. (1986). The Snowball Effect: Turnover Embedded in Communication Networks. Journal of Applied Psychology vol. 71, No. 1. New York: American Psychological Association.

Kuntjoro, Z.S. (2002). Komitmen Organisasi. http://www. e-psikologi.com/ MASALAH 1250702.htm. Diakses pada tanggal 17 Juni 2005 pkl. 22.20 WIB.

Munandar, A.S. (2001). Psikologi Industri dan Organisasi. Jakarta: UI Press. 
Mobley, W. (1986). Pergantian Karyawan; Sebab Akibat dan Pengendaliannya. (Terjemahan Nurul Iman). Jakarta: PT Pustaka Binaman Pressindo.

NN. Membedah Pandangan Karyawan Indonesia. Tabloid Human Capital. No. 10. tahun 2005. Jakarta: PT Temprint.

Panjaitan, F.D. (2005). Hubungan antara Karakteristik Pekerjaan dan Motivasi Berprestasi dengan Komitmen Organisasi. Skripsi (tidak diterbitkan). Yogyakarta: Fakultas Psikologi Universitas Gadjah Mada.

Robbins, S.P. (2003). Perilaku Organisasi. Jilid I. Jakarta: PT INDEKS Kelompok Gramedia.

Saefuddin, M.A. (1993). Organisasi dan Manajemen Industri. Yogyakarta: Liberty

Simamora, H. (2001). Manajemen Sumber Daya Manusia ed.2. Yogyakarta: STIE YKPN.

Stanton, William J. (1996). Prinsip Pemasaran, Jilid I. Jakarta: Erlangga

Staw, B.M. (1991). Psychological Dimensions of Organizational Behavior. New York: Macmillan.

Wijaya, G. (2003). Seri Hukum Bisnis: Tanggung Jawab Direksi Atas Kepailitan Perseroan. Jakarta: PT Raja Grafindo Persada. 
BIO DATA

Nama : Susatyo Yuwono

Tempat/Tanggal Lahir : Karanganyar / 24 Juni 1973

Alamat :

- Sentul 01/03 Sidoagung Godean Sleman 55564

- Jetak 01/07 Dagen Jaten Karanganyar 57771

No Telp : 085228010005

Pendidikan :

S1 : Fakultas Psikologi UGM, tahun 1998

Profesi Psikolog : Fakultas Psikologi UGM, tahun 2000

S2 : Prodi Psikologi Program Pascasarjana UGM, 2005 